\section{Business and biodiversity-a mutually profitable partnership}

The first week in April marks the staging of a major international conference, at London's Chatham House, entitled 'Biodiversity and Business - Putting Principles into Action'. Supported by Fauna \& Flora International's (FFI) Global Business Partnership and the Dutch and British Governments, the event provides a forum to discuss business opportunities, trailblazing initiatives and corporate strategy in the context of biodiversity conservation and sustainable use. The conference is an indication of how far we have come since the 'us and them' days of the donor-recipient relationship, where money changed hands across an unbridgeable philosophical divide. In recent years, the relationship between charity and business has developed into a genuine partnership. The opportunism of the one-off financial transaction has given way to a spirit of longterm collaboration, where finance is just one part of a multifaceted and mutually beneficial association. Refusing to work with the business community, therefore, is no longer simply a case of biting the hand that feeds. In the current global economic climate, a reluctance to engage in meaningful dialogue has much broader ecological and social repercussions.

During the last decade, we have witnessed a massive transfer of assets from the public to the private sector. Governments no longer hold the purse strings and they are increasingly being relegated to the role of regulators. As public sector money dries up, the challenge for conservation is to find new sources of funding to help champion the cause of biodiversity and sustainable use. The countries with the richest biodiversity are also those most in need of financial support. As private investment in developing countries increases, the key is to encourage sustainable use by diverting a significant proportion of this capital into enterprises that can have a positive impact on biodiversity. Globalization, megamergers and industrial privatization on a grand scale have all led to a situation in which major corporates exert an all-pervading influence on the planet.

Businesses affect biodiversity in many ways, the most obvious being activities such as mining, timber extraction or oil exploration. Why deny ourselves the opportunity to engage in a constructive dialogue that might lead to changes in management practice or to the adoption of a more environmentally favourable technical approach? Only by working with companies can we promote sustainable use, help them to establish environmental controls that minimize the ecological impact of their activities and demonstrate the value of consulting local stakeholders. If big business could be persuaded to set aside even a small percentage of the money in its corporate coffers for investment in biodiversity-friendly activities, the benefits to conservation would be staggering. The real debate is not whether we should work with multinationals, but how.

Why should the private sector heed the call of biodiversity conservation? In a world of endangered species, genuinely philanthropic company bosses are up there on the critical list alongside the mountain gorilla, the mpingo tree and the hyacinth macaw. Rather than relying on corporate charity, we need to inculcate a spirit of enlightened self-interest. Company chiefs are in the business of maximizing shareholder value. If we are to have any chance of influencing corporate policy and persuading global giants to incorporate biodiversity into their strategic planning process, we need to emphasize what is in it for them. Demonstrating how biodiversity can add business value is a critical success factor.

It is the responsibility of conservation to promote greater understanding of the relationship between biodiversity and business. We need to identify the key drivers that will persuade a greater proportion of the business community to take biodiversity seriously, highlighting the ways in which environmental factors can have a positive impact on their bottom line.

In recent years, companies have proved that responsible stewardship of biodiversity and commercial profitability need not necessarily be mutually exclusive options. The demand for organic food, certified wood products and ecotourism continues to grow unabated. Bioprospecting - which has not always benefited the local community as it should-enables pharmaceutical companies to derive new value from existing ecosystems. Consumer awareness has created a growing market for sustainable products and production practices that protect biodiversity.

The environmental record of a company is becoming a key criterion in the lending or investment decisions made by the financial services sector. Government regulations and tax incentives also play their part. International policy and regulation are creating new opportunities for businesses that are environmentally responsible, while heavier sanctions penalize those that are less ecoefficient. However, ecoefficiency is not simply about making cost savings and reducing liability. Changes in production methods and the development of new, sustainable products can lead to substantially higher profitability. Recent studies suggest that organ- 
izations that are attentive to environmental value reap corresponding financial rewards.

The more enlightened companies are looking beyond environmental compliance and actively cultivating partnerships with non-governmental organizations (NGOs) and other stakeholders. In any new business venture, there are inevitable conflicts of interest arising from the different value systems of the various stakeholders. Economic developments cannot improve local quality of life in isolation. By working in partnership with NGOs, businesses can ensure that the social and environmental dimensions are managed effectively. FFI launched its Global Business Partnership to advance understanding of the relationship between biodiversity and business. Founded by BP Amoco and Rio Tinto, the partnership comprises a range of commercial and industrial companies, all of which recognize the business value of having a strategic policy on the issue of biodiversity. It addresses issues such as corporate governance and leadership, developing models that promote the protection and wise use of biodiversity in the context of sustainable development. At first sight, business and biodiversity may appear to be unsuitable bedfellows. In reality, they each have much to gain from working in partnership. Managed carefully, an alliance between business and conservation can be transformed from a marriage of convenience into a match made in heaven. As with any healthy relationship, the secret of success is compromise, mutual understanding and respect for each other's values. It has taken many years to break down barriers and to build confidence on both sides. We need to capitalize on the atmosphere of mutual trust that now exists between the partners by finding new ways of working together in the long term. As many species will tell you, the more protracted and elaborate the courtship, the more it makes sense to mate for life.

Mark Rose

Fauna \& Flora International, Great Eastern House, Tenison Road, Cambridge CB1 2TT, UK

(e-mail: markrose1@aol.com) 